\title{
Interaksi Genotipe x Lingkungan Hasil dan Komponen Hasil 14 Genotipe Tomat di Empat Lingkungan Dataran Rendah
}

\author{
Genotype $x$ Environment Interaction of Yield and Yield Components \\ of 14 Tomato Genotypes in Four Lowland Environments
}

\author{
Suprayanti Martia Dewi ${ }^{1}$, Sobir $^{2}$, dan Muhamad Syukur ${ }^{2 *}$ \\ ${ }^{1}$ Program Studi Pemuliaan dan Bioteknologi Tanaman, Sekolah Pascasarjana, Institut Pertanian Bogor \\ ${ }^{2}$ Departemen Agronomi dan Hortikultura, Fakultas Pertanian, Institut Pertanian Bogor \\ (Bogor Agricultural University), Jl. Meranti, Kampus IPB, Darmaga, Bogor 16680, Indonesia
}

Diterima 9 September 2014/Disetujui 21 November 2014

\begin{abstract}
Genotype x environment interaction (GxE) information is needed by plant breeders to assist the identification of superior genotype. Stability analysis can be done if there is a GxE interaction, to show the stability of a genotype when planted in different environments. This study aimed to estimate the effects of genotype $x$ environment interaction on yield and yield components of fruit weight per plant as well as to look at the stability of 14 tomato genotypes at four lowland locations. The study was conducted at four locations, namely Purwakarta, Lombok, Tajur and Leuwikopo. Experiments at each location was arranged in a randomized complete block design with three replications. Stability analysis was performed using the AMMI model. Fruit weight, fruit diameter, number of fruits per plant and total fruit weight per plant characters showed highly significant genotype $x$ environment interactions. Variability due to the effect of GxE interaction based on a AMMI2 contributed by $88.50 \%$. IPBT3, IPBT33, IPBT34, IPBT60 and Intan were stable genotypes under AMMI model.
\end{abstract}

Keywords: AMMI, multilocation trials

\section{ABSTRAK}

Informasi tentang interaksi genotipex lingkungan (GxE) diperlukan pemulia tanaman untukmembantu proses identifikasi genotipe unggul. Analisis stabilitas dapat dilakukan apabila terdapat interaksi GxE, untuk menunjukkan kestabilan suatu genotipe apabila ditanam pada lingkungan yang berbeda. Penelitian ini bertujuan untuk menduga pengaruh interaksi genotipe $x$ lingkungan terhadap hasil dan hasil komponen bobot buah per tanaman serta untuk melihat kestabilan hasil dari 14 genotipe tomat pada empat lokasi dataran rendah. Penelitian dilakukan di empat lokasi, yaitu Purwakarta, Lombok, Tajur dan Leuwikopo. Percobaan di tiap lokasi dilakukan dengan menggunakan rancangan kelompok lengkap teracak dengan 3 ulangan di tiap lokasi. Metode analisis stabilitas dilakukan dengan menggunakan metode AMMI. Karakter bobot per buah, diameter buah, jumlah buah per tanaman dan bobot buah per tanaman memiliki interaksi genotipe x lingkungan yang sangat nyata. Keragaman karena pengaruh interaksi berdasarkan model AMMI2 sebesar 88.50\%. IPBT3, IPBT33, IPBT34, IPBT60 dan Intan merupakan genotipe stabil berdasarkan model AMMI.

Kata kunci: AMMI, uji multilokasi

\section{PENDAHULUAN}

Tomat (Solanum lycopersicum L.) merupakan salah satu komoditas hortikultura penting di Indonesia. Tomat dapat dimanfaatkan dalam bentuk segar maupun olahan, contohnya sebagai pewarna makanan, bahan kosmetika dan obat-obatan. Budidaya tanaman tomat umumnya adaptif pada dataran tinggi, namun belakangan ini areal penanaman tomat dataran tinggi terbatas karena terjadi persaingan penanaman komoditas pertanian lain dan banyaknya daerah

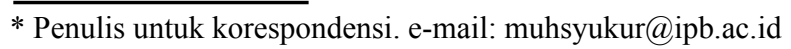

konservasi yang terletak di dataran tinggi. Oleh karena itu, perlu dilakukan perluasan areal tanam tomat ke daerah dataran menengah dan rendah (Purwati, 2007).

Perluasan areal tanam ke dataran rendah menyebabkan adanya perbedaan kondisi lingkungan sehingga varietas yang dikembangkan tidak berproduksi optimum. Purwati (2007) menyatakan dataran tinggi mampu menghasilkan produksi tomat sebesar 26.60 ton $\mathrm{ha}^{-1}$, sedangkan potensi produksi tomat dataran rendah masih sangat rendah yaitu $0.25 \mathrm{~kg} \operatorname{tanaman}^{-1}$ atau setara dengan 6 ton ha ${ }^{-1}$. Hasil tomat hibrida adaptif dataran rendah hingga tinggi yang ditanam di dataran medium (550 m dpl) menurut Purwati (2009) hanya menghasilkan $1.95 \mathrm{~kg}_{\text {tanaman }}^{-1}$ dari potensi hasil 
$3 \mathrm{~kg}$ tanaman ${ }^{-1}$, dengan kata lain telah terjadi penurunan hasil sebesar 35\%. Surmaini et al. (2008) mengemukakan bahwa salah satu faktor yang mempengaruhi rendahnya produksi di dataran rendah adalah suhu. Perbedaan suhu dapat mengakibatkan perbedaan respons tanaman, dimana peningkatan suhu menyebabkan peningkatan transpirasi tanaman sehingga terjadi penurunan produktivitas tanaman, peningkatan konsumsi air, waktu pematangan buah atau biji yang singkat, penurunan mutu hasil, dan pendorong berkembangnya hama penyakit tanaman. Oleh karena itu, usaha pemuliaan tomat unggul dataran rendah perlu dilakukan.

Salah satu tahapan yang harus dilakukan untuk mengembangkan tomat dataran rendah adalah menguji genotipe unggul dataran rendah di beberapa lokasi. Pengujian di beberapa lokasi perlu dilakukan untuk mengetahui respons genotipe pada lingkungan dengan tipe tanah, ketinggian, suhu, lintang, iklim dan musim yang berbeda. Dari hasil pengujian stabilitas hasil dapat ditentukan genotipe tertentu pada kondisi lingkungan yang berbeda dapat beradaptasi secara luas atau spesifik lokasi (Suryati et al., 2008). Pengembangan genotipe unggul spesifik lokasi dapat diarahkan untuk mendapatkan varietas spesifik lingkungan, sementara varietas yang unggul di semua lingkungan dapat dilepas menjadi varietas yang mampu beradaptasi luas (Nusifera dan Agung, 2008; Ganefianti et al., 2009).

Analisis ragam gabungan di beberapa lokasi akan menunjukkan informasi ada atau tidaknya interaksi yang terjadi antara genotipe dengan lingkungan. Interaksi genotipe $\mathrm{x}$ lingkungan (GxE) diperlukan pemulia untuk membantu proses identifikasi genotipe unggul. Analisis stabilitas dapat dilakukan apabila terdapat interaksi GxE untuk menunjukkan kestabilan suatu genotipe apabila ditanam pada lingkungan yang berubah atau berbeda (Syukur et al., 2012).

Analisis stabilitas dapat dilakukan menggunakan metode AMMI (Mattjik dan Sumertajaya, 2000). AMMI sangat efektif menjelaskan interaksi genotipe dengan lingkungan dengan keakuratan dugaan respons interaksi genotipe $\mathrm{x}$ lingkungan yang tinggi. Analisis AMMI melalui visualisasi biplot mampu menginterpretasikan data uji multilokasi dengan menunjukkan interaksi galur dengan lokasi sehingga terbentuk pola sebaran titiktitik genotipe dengan kedudukan relatifnya pada lokasi dimana hasil penguraian nilai singular diplotkan antara satu komponen genotipe dengan komponen lokasi secara simultan (Sujiprihati et al., 2006). Biplot AMMI kemudian meringkas pola hubungan antara galur, antara lingkungan, dan antara keduanya sehingga dihasilkan nilai AMMI1 dan rataan. Biplot antara nilai AMMI2 dan nilai AMMI1 bisa ditambahkan jika AMMI2 nyata. Dalam visualisasi biplot, genotipe dapat dikatakan stabil apabila berada dekat dengan sumbu dan genotipe yang berada jauh dari sumbu namun dekat dengan garis lokasi digolongkan genotipe yang spesifik lokasi (Mattjik dan Sumertajaya, 2000; Ganefianti et al., 2009). AMMI juga telah digunakan untuk melihat kestabilan beberapa komoditas lain seperti cabai (Ganefianti et al., 2009), jagung (Sujiprihati et al., 2006) dan bengkuang (Nusifera dan Agung, 2008). Penelitian ini bertujuan untuk menduga pengaruh genotipe, lokasi dan interaksi genotipe $\mathrm{x}$ lingkungan terhadap komponen hasil dan hasil buah per tanaman serta untuk melihat kestabilan hasil dari 14 genotipe tomat pada empat lokasi dataran rendah menggunakan analisis AMMI.

\section{BAHAN DAN METODE}

Penelitian dilaksanakan di empat lokasi, yaitu Purwakarta, Lombok, Tajur dan Leuwikopo dari bulan April 2012 hingga Agustus 2013 (Tabel 1). Bahan yang digunakan adalah 14 genotipe tomat (galur murni) koleksi Tim Pemuliaan Tomat Bagian Genetika dan Pemuliaan Tanaman, IPB, yang terdiri atas IPBT3, IPBT8, IPBT30, IPBT33, IPBT34, IPBT43, IPBT53, IPBT57, IPBT60, IPBT64, IPBT78, Intan, Ratna dan Karina. Percobaan di setiap lokasi dilakukan dengan menanam 14 genotipe dalam rancangan kelompok lengkap teracak dengan tiga ulangan dimana ulangan tersarang dalam lokasi. Setiap satuan percobaan terdiri atas 20 tanaman.

Kegiatan percobaan diawali dengan kegiatan penyemaian. Media tanam yang digunakan adalah media campuran kompos dan tanah (1:1). Bibit siap untuk dipindahkan ke lapangan setelah bibit mempunyai 3-4 helai daun. Bedengan dibuat dengan ukuran $1 \mathrm{~m}$ x $25 \mathrm{~m}$ dengan jarak antar bedengan $30 \mathrm{~cm}$ dan tinggi bedengan $20 \mathrm{~cm}$. Jarak tanam yang digunakan adalah $50 \mathrm{~cm} \times 50$ $\mathrm{cm}$ (double row). Pupuk dasar yang diaplikasikan meliputi pupuk kandang sapi 20 ton ha ${ }^{-1}$, NPK (16:16:16) 4 ton ha-1, serta kapur 2 ton ha $^{-1}$ yang diberikan 5 hari sebelum tanam. Kegiatan pemeliharaan yang dilakukan setelah bibit tomat ditanam antara lain penyiraman, pengajiran, pemupukan, penyiangan gulma dan pengendalian hama dan penyakit.

Pestisida yang digunakan adalah fungisida berbahan aktif mankozeb $80 \%$ dan propineb $70 \%$ dengan konsentrasi $2 \mathrm{~g} \mathrm{~L}^{-1}$, insektisida berbahan aktif profenofos $500 \mathrm{~g} \mathrm{~L}^{-1}$

Tabel 1. Kondisi lingkungan di empat lokasi tempat percobaan selama pertumbuhan

\begin{tabular}{lcccc}
\hline Uraian & Purwakarta & Lombok & Tajur & Leuwikopo \\
\hline Karakteristik lahan & Bekas sawah & Bekas sawah & Kebun Percobaan IPB & Kebun Percobaan IPB \\
Ketinggian wilayah (m dpl) & 270 & 16 & 250 & 190 \\
Bulan & Januari-April & April-Agustus & Januari-April & April-Agustus \\
Tahun & 2013 & 2013 & 2013 & 2012 \\
Curah hujan $\left(\mathrm{mm} \mathrm{bulan}^{-1}\right)$ & 17.5 & 131.25 & 394 & 175.4 \\
\hline
\end{tabular}


dengan konsentrasi $2 \mathrm{ml} \mathrm{L}^{-1}$ dan akarisida berbahan aktif dikofol dengan konsentrasi $2 \mathrm{ml} \mathrm{L}^{-1}$. Pupuk daun diberikan saat pertumbuhan vegetatif, sedangkan Pupuk bunga diberikan pada saat generatif dengan konsentrasi masingmasing $2 \mathrm{~g} \mathrm{~L}^{-1}$. Aplikasi pupuk daun dan bunga diberikan bersamaan dengan penyemprotan pestisida.

Pemanenan dilakukan bila tanaman telah berumur 80-90 HST (hari setelah tanam) atau sudah 50\% matang penuh dengan kriteria bobot buah telah maksimal, bentuk buah padat dan buah telah mengalami perubahan warna dari hijau menjadi kuning kemerah-merahan. Pemanenan dilakukan secara bertahap sesuai tingkat kematangan buah pada tanaman.

Pengamatan dilakukan pada 10 tanaman contoh dari setiap satuan percobaan. Karakter yang diamati adalah bobot per buah (g), diameter buah (mm), jumlah buah per tanaman (buah) dan bobot buah per tanaman (g). Pengamatan bobot per buah dan ukuran buah dilakukan pada buah yang sama yang dipanen pada panen kedua hingga keempat.

Analisis data dilakukan menggunakan aplikasi SAS versi 9.1.3. Stabilitas hasil bobot buah per tanaman 14 genotipe ditentukan menggunakan analisis stabilitas model AMMI dengan menggunakan biplot sebagai alat bantu visual untuk menginterpretasikan hasil analisis (Gauch, 2006).

\section{HASIL DAN PEMBAHASAN}

\section{Interaksi Genotipe x Lingkungan}

Data mempunyai ragam homogen untuk semua lokasi uji sebesar $0.38(\mathrm{p}=0.38)$ sehingga dapat dilanjutkan ke analisis ragam gabungan berdasarkan uji Barlet. Hasil analisis kuadrat tengah gabungan 14 genotipe yang diuji pada empat lokasi di dataran rendah disajikan pada Tabel 2. Hasil analisis ragam gabungan menunjukkan genotipe berpengaruh sangat nyata untuk semua karakter pengamatan yaitu bobot per buah, diameter buah, bobot buah per tanaman dan jumlah buah per tanaman genotipe. Lokasi berpengaruh sangat nyata untuk semua karakter sehingga mengidentifikasi adanya perbedaan hasil pada masing-masing lokasi. Interakasi genotipe $\mathrm{x}$ lokasi juga menunjukkan pengaruh yang sangat nyata untuk semua karakter sehingga analisis AMMI dapat dilakukan (Sujiprihati et al., 2006). Adanya interaksi GxE pada bobot buah per tanaman menunjukkan genotipe dengan potensi hasil yang tinggi pada lokasi tertentu belum tentu hasilnya akan tetap tinggi pada lokasi lainnya dengan kata lain keragaan suatu genotipe secara nyata dipengaruhi oleh kondisi lingkungan yang beragam (Ambarwati dan Yudono, 2003; Lestari et al., 2010; Kusmana, 2005; Sujiprihati et al., 2006; Mattjik dan Sumertajaya, 2000). Koefisien keragaman berkisar antara 7.91-29.24\% dengan koefisen tertinggi terdapat pada bobot buah per tanaman. Tingginya koefisien keragaman ini diduga karena adanya perbedaan kondisi lingkungan yang berpengaruh terhadap hasil.

Genotipe IPBT78 memiliki rata-rata bobot buah tertinggi di semua lokasi sebesar $45.72 \mathrm{~g}$ per buah (Tabel 3). IPBT3, IPBT8, IPBT64, IPBT78, Ratna dan Intan menghasilkan bobot buah yang paling besar untuk lokasi Purwakarta. Bobot buah terbesar pada lokasi Lombok adalah IPBT60, IPBT78 dan Ratna. Bobot buah terbesar pada lokasi Tajur dihasilkan oleh genotipe IPBT8, IPBT43, IPBT64, IPBT78, Ratna dan Karina. Bobot buah terbesar di Leuwikopo dihasilkan oleh selain genotipe IPBT3, IPBT30, IPBT33, IPBT34 dan IPBT53. IPBT78 dan Ratna selalu menghasilkan genotipe dengan bobot yang paling tinggi di semua lokasi. Hal ini dapat menjadi nilai tambah bagi pemulia untuk mengembangkan genotipe-genotipe tersebut sebagai genotipe unggul dataran rendah. Rata-rata diameter buah di semua lokasi berkisar antara 26.83-44.35 $\mathrm{mm}$. Diameter buah paling besar ditunjukkan oleh IPBT78 dan Intan yaitu dari $41.44-44.35 \mathrm{~mm}$. Genotipe IPBT3, IPBT30, IPBT33 dan IPBT53 mempunyai diameter buah yang paling kecil serta memiliki bobot buah yang relatif kecil (Tabel 4).

Tabel 5 menunjukkan bahwa genotipe yang menghasilkan jumlah buah tertinggi adalah IPBT33 (85.65 buah per tanaman) dan tidak berbeda nyata dengan IPBT3 dan IPBT53 yang masing-masing sebanyak 74.45 dan 78.19 buah per tanaman. Jumlah buah per tanaman terendah ditunjukkan oleh IPBT8, IPBT57, IPBT64, IPBT78, Karina, Ratna dan Intan. Bobot buah per tanaman semua genotipe yang diuji pada genotipe untuk semua lokasi berkisar antara 609.41-1076.72 g (Tabel 6). Informasi rata-rata bobot buah per tanaman di semua lokasi menunjukan genotipe yang memiliki produksi per tanaman yang paling tinggi adalah IPBT64 dan IPBT78. Genotipe yang selalu memperlihatkan

Tabel 2. Kuadrat tengah untuk berbagai sifat tomat yang diamati pada empat lingkungan dataran rendah

\begin{tabular}{|c|c|c|c|c|c|}
\hline Sumber keragaman & $\mathrm{db}$ & Bobot per buah & Diameter buah & $\begin{array}{l}\text { Jumlah buah } \\
\text { per tanaman }\end{array}$ & $\begin{array}{l}\text { Bobot buah } \\
\text { per tanaman }\end{array}$ \\
\hline Lokasi (L) & 3 & $3,105.75^{* *}$ & $726.66^{* *}$ & $15,704.95^{* *}$ & $6,038,528.75^{* *}$ \\
\hline Ulangan/Lokasi & 8 & $135.57 * *$ & $35.81 * *$ & $924.34 * *$ & $268,307.33 * *$ \\
\hline Genotipe (G) & 13 & $1,542.03 * *$ & $334.65^{* *}$ & $5,058.98 * *$ & $279,268.25^{* *}$ \\
\hline GxL & 39 & $234.90 * *$ & $46.74 * *$ & $413.16^{* *}$ & $309,143.61 * *$ \\
\hline Galat & 104 & 49.81 & 7.92 & 192.97 & $61,104.19$ \\
\hline Koefisien keragama & & $25.70 \%$ & $7.91 \%$ & $30.35 \%$ & $29.24 \%$ \\
\hline
\end{tabular}

Keterangan: $* *$ menyatakan berpengaruh nyata pada taraf $1 \%$ 
J. Agron. Indonesia 43 (1) : 59 - 65 (2015)

Tabel 3. Bobot per buah 14 genotipe tomat pada empat lingkungan

\begin{tabular}{|c|c|c|c|c|c|}
\hline \multirow{2}{*}{ Genotipe } & Purwakarta & Lombok & Tajur & Leuwikopo & \multirow{2}{*}{ Rata-rata } \\
\hline & \multicolumn{4}{|c|}{ 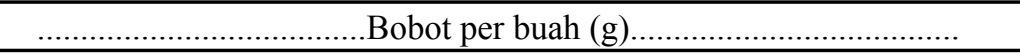 } & \\
\hline IPBT3 & $17.65 \mathrm{abc}$ & $17.71 \mathrm{cde}$ & $19.25 \mathrm{~d}$ & $10.64 \mathrm{cde}$ & $16.31 \mathrm{efg}$ \\
\hline IPBT8 & $30.82 \mathrm{ab}$ & $24.75 \mathrm{cde}$ & $55.49 \mathrm{ab}$ & $33.72 \mathrm{ab}$ & $36.19 \mathrm{abc}$ \\
\hline IPBT30 & $13.12 \mathrm{bc}$ & $11.32 \mathrm{e}$ & $18.12 \mathrm{~d}$ & $7.28 \mathrm{e}$ & $12.46 \mathrm{fg}$ \\
\hline IPBT33 & $8.74 \mathrm{c}$ & $17.75 \mathrm{cde}$ & $13.29 \mathrm{~d}$ & $9.43 \mathrm{cde}$ & $12.30 \mathrm{fg}$ \\
\hline IPBT34 & $13.27 b c$ & $33.86 \mathrm{bcd}$ & $28.72 \mathrm{~cd}$ & $18.02 \mathrm{bcde}$ & $23.47 \mathrm{de}$ \\
\hline IPBT43 & $11.35 \mathrm{bc}$ & $37.22 \mathrm{bc}$ & $51.99 \mathrm{ab}$ & 20.49abcde & $30.26 \mathrm{bcd}$ \\
\hline IPBT53 & $10.88 \mathrm{bc}$ & 14.90de & $12.55 \mathrm{~d}$ & 8.16de & $11.62 \mathrm{~g}$ \\
\hline IPBT57 & $16.04 b c$ & $24.00 \mathrm{cde}$ & $27.10 \mathrm{~cd}$ & 20.26abcde & $21.85 \mathrm{def}$ \\
\hline IPBT60 & $8.80 \mathrm{c}$ & $45.38 \mathrm{ab}$ & $31.38 \mathrm{~cd}$ & $31.05 \mathrm{ab}$ & $29.15 \mathrm{~cd}$ \\
\hline IPBT64 & $29.34 \mathrm{ab}$ & $28.72 \mathrm{bcde}$ & $57.17 \mathrm{ab}$ & 25.07abcde & $35.08 \mathrm{bc}$ \\
\hline IPBT78 & $36.85 a$ & $62.52 \mathrm{a}$ & $51.77 \mathrm{ab}$ & $31.75 \mathrm{ab}$ & $45.72 \mathrm{a}$ \\
\hline Karina & $15.03 \mathrm{bc}$ & $36.04 b c$ & $43.01 b c$ & $29.01 \mathrm{abc}$ & $30.77 \mathrm{bcd}$ \\
\hline Ratna & $26.51 \mathrm{abc}$ & $45.18 \mathrm{ab}$ & $58.11 \mathrm{ab}$ & $28.05 \mathrm{abcd}$ & $39.46 \mathrm{ab}$ \\
\hline Intan & $27.53 \mathrm{abc}$ & $25.94 \mathrm{bcde}$ & $66.99 \mathrm{a}$ & $39.94 \mathrm{a}$ & $40.10 \mathrm{ab}$ \\
\hline Rata-rata & $19.00 \mathrm{C}$ & $30.38 \mathrm{AB}$ & $38.21 \mathrm{~A}$ & $22.35 \mathrm{BC}$ & \\
\hline
\end{tabular}

Keterangan: Angka yang diikuti huruf kecil yang sama pada kolom yang sama dan angka yang diikuti huruf kapital yang sama pada baris yang sama menunjukkan tidak berbeda nyata berdasarkan uji lanjut Duncan pada taraf $5 \%$

Tabel 4. Diameter buah 14 genotipe tomat pada empat lingkungan

\begin{tabular}{|c|c|c|c|c|c|}
\hline \multirow{2}{*}{ Genotipe } & Purwakarta & Lombok & Tajur & Leuwikopo & \multirow{2}{*}{ Rata-rata } \\
\hline & \multicolumn{4}{|c|}{ 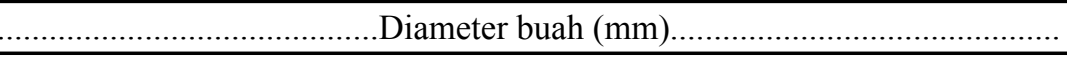 } & \\
\hline IPBT3 & $30.18 \mathrm{abcd}$ & 29.93 def & $27.66 \mathrm{ef}$ & $31.35 \mathrm{de}$ & $29.78 \mathrm{e}$ \\
\hline IPBT8 & $34.83 \mathrm{ab}$ & $34.32 \mathrm{bcde}$ & $45.88 \mathrm{ab}$ & $44.36 \mathrm{ab}$ & $39.85 b c$ \\
\hline IPBT30 & $27.72 \mathrm{bcd}$ & $26.14 f$ & $33.20 \mathrm{de}$ & $27.69 \mathrm{e}$ & $28.69 \mathrm{e}$ \\
\hline IPBT33 & $23.55 \mathrm{~d}$ & $31.19 \mathrm{cdef}$ & $27.71 \mathrm{ef}$ & $31.52 \mathrm{de}$ & $28.49 \mathrm{e}$ \\
\hline IPBT34 & $26.34 \mathrm{~cd}$ & $38.82 \mathrm{abc}$ & $37.51 \mathrm{~cd}$ & $35.12 \mathrm{cde}$ & $34.45 \mathrm{~d}$ \\
\hline IPBT43 & $25.05 \mathrm{~cd}$ & $39.36 \mathrm{ab}$ & $44.14 \mathrm{abc}$ & $37.68 \mathrm{bcd}$ & $36.56 \mathrm{~cd}$ \\
\hline IPBT53 & $25.04 \mathrm{~cd}$ & $28.52 \mathrm{ef}$ & $23.60 \mathrm{f}$ & $30.16 \mathrm{de}$ & $26.83 \mathrm{e}$ \\
\hline IPBT57 & 31.04abcd & $34.50 \mathrm{bcde}$ & $40.52 \mathrm{bcd}$ & $37.36 \mathrm{bcd}$ & $35.85 \mathrm{~cd}$ \\
\hline IPBT60 & $24.38 \mathrm{~cd}$ & $43.23 \mathrm{a}$ & $40.03 \mathrm{bcd}$ & $45.85 \mathrm{a}$ & $38.38 \mathrm{bcd}$ \\
\hline IPBT64 & $35.08 \mathrm{ab}$ & $34.09 \mathrm{bcdef}$ & $46.91 \mathrm{ab}$ & $37.44 \mathrm{bcd}$ & $38.38 \mathrm{bcd}$ \\
\hline IPBT78 & $36.60 \mathrm{a}$ & $44.71 \mathrm{a}$ & $42.32 b c$ & $42.13 \mathrm{abc}$ & $41.44 \mathrm{ab}$ \\
\hline Karina & $27.67 \mathrm{bcd}$ & $37.85 \mathrm{abcd}$ & $41.20 \mathrm{bcd}$ & $43.57 \mathrm{ab}$ & $37.57 \mathrm{bcd}$ \\
\hline Ratna & $31.70 \mathrm{abc}$ & $38.16 a b c$ & $42.20 \mathrm{bc}$ & $37.47 \mathrm{bcd}$ & $37.38 \mathrm{bcd}$ \\
\hline Intan & $35.39 \mathrm{ab}$ & $42.11 \mathrm{ab}$ & $51.73 \mathrm{a}$ & $48.18 \mathrm{a}$ & $44.35 \mathrm{a}$ \\
\hline Rata-rata & $29.61 \mathrm{~B}$ & $35.92 \mathrm{~A}$ & $38.90 \mathrm{~A}$ & $37.85 \mathrm{~A}$ & \\
\hline
\end{tabular}

Keterangan: Angka yang diikuti huruf kecil yang sama pada kolom yang sama dan angka yang diikuti huruf kapital yang sama pada baris yang sama menunjukkan tidak berbeda nyata berdasarkan uji lanjut Duncan pada taraf $5 \%$

bobot buah per tanaman yang baik di masing-masing lokasi adalah IPBT60 dan IPBT64, namun IPBT78 juga menunjukkan hasil yang relatif stabil di keempat lokasi yaitu berkisar 964.91-1204.84 g per tanaman. Genotipe yang memiliki produktivitas hasil lebih dari 1,000 g per tanaman berdasarkan rata-rata genotipe di semua lokasi adalah IPBT43, IPBT64 dan IPBT78 dengan produktivitas mencapai 21.54, 22.97 dan 22.71 ton $\mathrm{ha}^{-1}$. 
Tabel 5. Jumlah buah per tanaman 14 genotipe tomat pada empat lingkungan

\begin{tabular}{|c|c|c|c|c|c|}
\hline \multirow{2}{*}{ Genotipe } & Purwakarta & Lombok & Tajur & Leuwikopo & \multirow{2}{*}{ Rata-rata } \\
\hline & \multicolumn{4}{|c|}{. } & \\
\hline IPBT3 & $37.83 \mathrm{ab}$ & $68.30 \mathrm{ab}$ & $87.43 \mathrm{ab}$ & $104.24 \mathrm{ab}$ & $74.45 \mathrm{ab}$ \\
\hline IPBT8 & $9.94 \mathrm{ab}$ & $21.45 \mathrm{de}$ & $28.47 \mathrm{~d}$ & $35.48 \mathrm{c}$ & $23.84 \mathrm{e}$ \\
\hline IPBT30 & $29.53 \mathrm{ab}$ & $7.17 \mathrm{e}$ & $70.47 \mathrm{abc}$ & $126.29 \mathrm{a}$ & $58.36 \mathrm{bc}$ \\
\hline IPBT33 & $40.00 \mathrm{ab}$ & $81.77 \mathrm{a}$ & $92.00 \mathrm{a}$ & $128.82 \mathrm{a}$ & $85.65 \mathrm{a}$ \\
\hline IPBT34 & $21.67 \mathrm{ab}$ & $26.88 \mathrm{cde}$ & 61.30abcd & $67.08 \mathrm{bc}$ & $44.23 \mathrm{~cd}$ \\
\hline IPBT43 & $11.17 \mathrm{ab}$ & $61.61 \mathrm{abc}$ & $58.00 \mathrm{abcd}$ & $48.64 \mathrm{c}$ & $44.85 \mathrm{~cd}$ \\
\hline IPBT53 & $49.31 \mathrm{a}$ & 58.38abcd & $91.73 \mathrm{a}$ & $113.33 \mathrm{a}$ & $78.19 \mathrm{ab}$ \\
\hline IPBT57 & $10.08 \mathrm{ab}$ & 43.00abcde & $53.27 \mathrm{abcd}$ & $45.47 \mathrm{c}$ & $37.96 \mathrm{de}$ \\
\hline IPBT60 & $49.56 \mathrm{a}$ & $40.87 \mathrm{bcde}$ & $53.40 \mathrm{abcd}$ & $32.86 c$ & $44.17 \mathrm{~cd}$ \\
\hline IPBT64 & $13.56 \mathrm{ab}$ & 44.57abcde & $27.47 d$ & $50.51 \mathrm{c}$ & $34.02 \mathrm{de}$ \\
\hline IPBT78 & $25.95 \mathrm{ab}$ & $36.93 \mathrm{bcde}$ & $24.20 \mathrm{~d}$ & $31.29 \mathrm{c}$ & $29.59 \mathrm{de}$ \\
\hline Karina & $5.40 \mathrm{~b}$ & $14.92 \mathrm{e}$ & $44.53 \mathrm{~cd}$ & $50.25 \mathrm{c}$ & $28.78 \mathrm{de}$ \\
\hline Ratna & $8.83 b$ & $7.93 \mathrm{e}$ & $49.27 \mathrm{bcd}$ & $56.98 \mathrm{c}$ & $30.75 \mathrm{de}$ \\
\hline Intan & $5.44 \mathrm{~b}$ & $20.62 \mathrm{de}$ & $33.93 \mathrm{~cd}$ & $43.46 \mathrm{c}$ & $25.86 \mathrm{de}$ \\
\hline Rata-rata & $22.73 \mathrm{C}$ & $38.17 \mathrm{BC}$ & 55.39AB & $66.77 \mathrm{~A}$ & \\
\hline
\end{tabular}

Keterangan: Angka yang diikuti huruf kecil yang sama pada kolom yang sama dan angka yang diikuti huruf kapital yang sama pada baris yang sama menunjukkan tidak berbeda nyata berdasarkan uji lanjut Duncan pada taraf $5 \%$

Tabel 6. Bobot buah per tanaman 14 genotipe tomat pada empat lingkungan

\begin{tabular}{|c|c|c|c|c|c|}
\hline \multirow{2}{*}{ Genotipe } & Purwakarta & Lombok & Tajur & Leuwikopo & \multirow{2}{*}{ Rata-rata } \\
\hline & \multicolumn{4}{|c|}{$\ldots$} & \\
\hline IPBT3 & $644.21 \mathrm{ab}$ & 791.07bcde & $1141.77 \mathrm{bcd}$ & $886.24 \mathrm{ab}$ & $865.82 \mathrm{abc}$ \\
\hline IPBT8 & $299.64 \mathrm{ab}$ & $354.20 \mathrm{ef}$ & $883.39 \mathrm{bcd}$ & $1165.83 \mathrm{ab}$ & $675.77 \mathrm{bc}$ \\
\hline IPBT30 & $392.06 \mathrm{ab}$ & $70.60 \mathrm{f}$ & $1140.77 \mathrm{bcd}$ & $834.20 b$ & $609.41 \mathrm{c}$ \\
\hline IPBT33 & $349.62 \mathrm{ab}$ & $782.02 \mathrm{bcdef}$ & $767.86 \mathrm{~d}$ & $1042.01 \mathrm{ab}$ & $735.38 \mathrm{abc}$ \\
\hline IPBT34 & $299.45 \mathrm{ab}$ & 817.89 bcde & 1256.46abcd & $1069.30 \mathrm{ab}$ & $860.78 \mathrm{abc}$ \\
\hline IPBT43 & $127.47 b$ & $1628.22 \mathrm{a}$ & 1304.75abcd & $977.20 \mathrm{ab}$ & $1009.41 \mathrm{ab}$ \\
\hline IPBT53 & $539.00 \mathrm{ab}$ & $480.17 \mathrm{def}$ & $816.46 \mathrm{~cd}$ & $865.94 b$ & $675.39 b c$ \\
\hline IPBT57 & $163.72 b$ & $670.49 \mathrm{bcdef}$ & $1582.99 \mathrm{ab}$ & 893.19ab & $827.60 \mathrm{abc}$ \\
\hline IPBT60 & $426.60 \mathrm{ab}$ & 1115.90abcd & 1214.90abcd & $1041.47 \mathrm{ab}$ & $949.72 \mathrm{abc}$ \\
\hline IPBT64 & 391.99ab & $1257.94 \mathrm{ab}$ & $1498.77 \mathrm{abc}$ & $1158.20 \mathrm{ab}$ & $1076.72 \mathrm{a}$ \\
\hline IPBT78 & 964.91a & $1204.84 \mathrm{abc}$ & $1051.23 \mathrm{bcd}$ & $1037.23 \mathrm{ab}$ & $1064.55 a$ \\
\hline Karina & $82.61 b$ & $306.54 \mathrm{ef}$ & 1423.95abcd & $1212.56 \mathrm{ab}$ & $756.42 \mathrm{abc}$ \\
\hline Ratna & $274.54 \mathrm{ab}$ & $174.75 \mathrm{ef}$ & $1886.85 \mathrm{a}$ & $1593.83 \mathrm{a}$ & $982.49 \mathrm{ab}$ \\
\hline Intan & $147.35 b$ & $544.27 \mathrm{cdef}$ & $928.11 \mathrm{bcd}$ & $1360.59 \mathrm{ab}$ & $745.08 \mathrm{abc}$ \\
\hline Rata-rata & $364.51 \mathrm{C}$ & $728.49 \mathrm{~B}$ & $1207.02 \mathrm{~A}$ & $1081.27 \mathrm{AB}$ & \\
\hline
\end{tabular}

Keterangan: Angka yang diikuti huruf kecil yang sama pada kolom yang sama dan angka yang diikuti huruf kapital yang sama pada baris yang sama menunjukkan tidak berbeda nyata berdasarkan uji lanjut Duncan pada taraf $5 \%$

\section{Stabilitas Hasil}

Stabilitas suatu genotipe merupakan kemampuan genotipe tersebut untuk hidup pada berbagai lingkungan yang berbeda dan fenotipenya tidak mengalami banyak perubahan di tiap-tiap lokasi percobaan (Syukur et al. 2012). Dari hasil analisis ragam Tabel 7 terlihat bahwa pengaruh utama (lingkungan dan genotipe) dan pengaruh interaksi genotipe dengan lingkungan nyata pada nilai peluang $<0.001$. Hasil ini menunjukkan bahwa produksi tomat sangat dipengaruhi 
oleh faktor genotipe dan lingkungan. Nilai F-hitung untuk lokasi (22.51) kemudian disusul oleh interaksi GxE (5.06), sedangkan pengaruh genotipe memiliki nilai paling kecil (4.57). Jumlah kuadrat faktor lokasi setelah dibandingkan dengan jumlah kuadrat total menghasilkan nilai yang paling besar di antara faktor lain, sehingga faktor lokasi diindikasikan sebagai penyumbang keragaman yang paling besar untuk karakter bobot per tanaman. Analisis AMMI menunjukkan bahwa karakter bobot per tanaman tomat sangat bergantung pada kondisi lokasi tempat penanaman dan genotipe yang digunakan. Mattjik dan Sumertajaya (2000) menyatakan bahwa jika pengaruh interaksi GxE nyata terhadap produksi berarti jenis genotipe tertentu akan tumbuh baik pada lokasi tertentu, tetapi tidak begitu halnya jika ditanam pada lokasi yang lain tergantung akan besarnya pengaruh interaksi GxE.

Kontribusi keragaman pengaruh interaksi yang mampu diterangkan oleh masing-masing komponen AMMI1, AMMI2, dan AMMI3 adalah masing-masing sebesar $60.2 \%$, 28.3\% dan $11.5 \%$ (Gambar 1). Berdasarkan nilai kontribusi keragaman tersebut terlihat bahwa dua komponen pertama memiliki peranan yang dominan dalam menerangkan keragaman pengaruh interaksi yaitu sebesar $88.50 \%$. Genotipe stabil akan menunjukkan

Tabel 7. Analisis ragam AMMI3 14 genotipe tomat di empat lokasi untuk peubah bobot buah per tanaman

\begin{tabular}{lcrrrc}
\hline Sumber keragaman & $\mathrm{db}$ & \multicolumn{1}{c}{$\mathrm{JK}$} & $\mathrm{KT}$ & F-hitung & Prob \\
\hline Lokasi & 3 & $18,115,586$ & $6,038,529$ & 22.51 & $<0.001$ \\
Ulangan/Lokasi & 8 & $2,146,459$ & 268,307 & 4.39 & $<0.001$ \\
Genotipe & 13 & $3,630,487$ & 279,268 & 4.57 & $<0.001$ \\
Genotipe x Lokasi & 39 & $12,056,601$ & 309,144 & 5.06 & $<0.001$ \\
AMMI1 & 15 & $7,263,533$ & 484,236 & 7.92 & $<0.001$ \\
AMMI2 & 13 & $3,407,439$ & 262,111 & 4.29 & $<0.001$ \\
AMMI3 & 11 & $1,385,629$ & 125,966 & 2.06 & 0.03 \\
Galat & 104 & $6,354,835$ & 61,104 & & \\
\hline Total & 167 & $42,303,968$ & & &
\end{tabular}

Keterangan: $\mathrm{db}=$ derajat bebas, $\mathrm{JK}=$ jumlah kuadrat, $\mathrm{KT}=$ kuadrat tengah

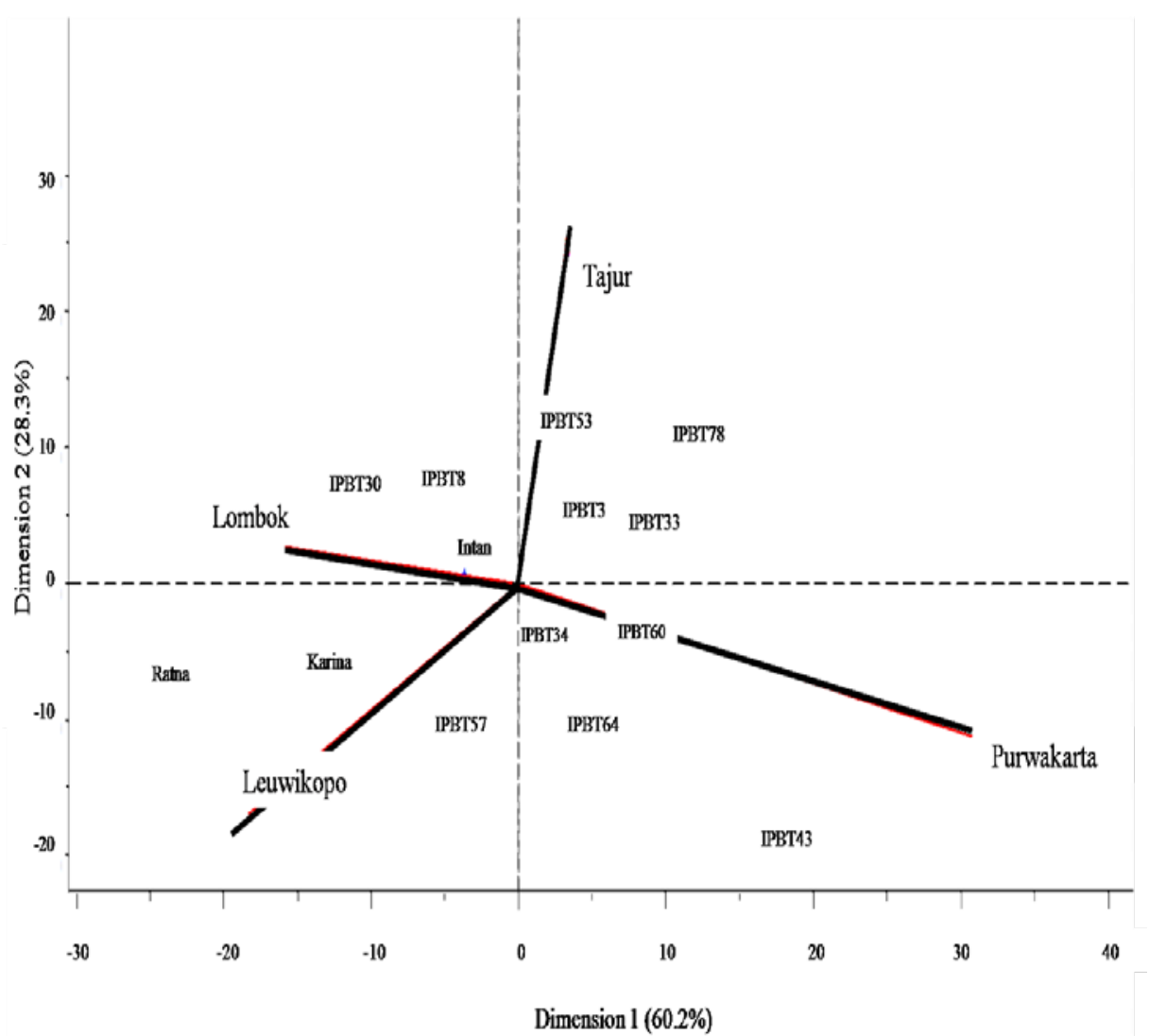

Gambar 1. Biplot pengaruh interaksi model AMMI2 pada karakter bobot buah per tanaman 14 genotipe tomat yang diuji (kesesuaian model: $88.50 \%$ ) 
respons yang sama pada kondisi lingkungan yang berbeda sehingga mampu mempertahankan tampilannya di berbagai lingkungan (Rasyad dan Idwar, 2010). Visualisasi biplot antara komponen 1 (AMMI) dan komponen 2 (AMMI2) untuk bobot buah per tanaman berdasarkan Gambar 1 menunjukkan genotipe IPBT3, IPBT33, IPBT34, IPBT60 dan Intan stabil pada empat lingkungan karena memiliki posisi titik sebaran yang paling dekat dengan titik sumbu $\mathrm{X}$ dan $\mathrm{Y}$.

\section{KESIMPULAN}

Karakter bobot per buah, diameter buah, jumlah buah per tanaman dan bobot buah per tanaman memiliki interaksi genotipe $\mathrm{x}$ lingkungan yang sangat nyata. Keragaman karena pengaruh interaksi berdasarkan model AMMI2 sebesar 88.50\%. Genotipe IPBT3, IPBT33, IPBT34, IPBT60 dan Intan dikatagorikan stabil pada empat lingkungan.

\section{UCAPAN TERIMA KASIH}

Terima kasih disampaikan kepada Kementerian Ristek melalui hibah SINas tahun 2013 atas nama Pusat Kajian Hortikultura Tropika (PKHT), Institut Pertanian Bogor.

\section{DAFTAR PUSTAKA}

Ambarwati, E., P. Yudono. 2003. Keragaan stabilitas hasil bawang merah. Ilmu Pertanian 10:1-10.

Ganefianti, D. W., D. Suryati, Hasannudin. 2009. Analisis stabilitas hasil enam genotipe cabai menggunakan Metode Additive Main Effect Multiplicative Interaction (AMMI). Akta Agrosia 12:147-154.

Gauch, H.G. 2006. Statistical analysis of yield trials by AMMI and GGE. Crop Sci. 46:1488-1500.

Kusmana. 2005. Uji stabilitas hasil umbi 7 genotipe kentang di dataran tinggi Pulau Jawa. J. Hort. 15:254-259.
Lestari, P.L., B. Abdullah, A. Junaedi, H. Aswidinnoor. 2010. Yield stability and adaptibility of aromatic New Plant Tipe (NPT) rice lines. J. Agron. Indonesia 38:199-204.

Mattjik, A.A., I.M. Sumertajaya. 2000. Perancangan Percobaan dengan Aplikasi SAS dan Minitab. Edisi ke-1. Bogor : IPB Press.

Nusifera, S., K. Agung. 2008. Analisis stabilitas hasil ubi 27 genotipe bengkuang (Pachyrhizus erosus L. Urban) di Jatinangor Jawa Barat berdasarkan model AMMI. Bul. Plasma Nutfah 14:19-25.

Purwati, E. 2007. Varietas unggul harapan tomat hibrida $\left(\mathrm{F}_{1}\right)$ dari BALITSA. Iptek Hortikultura 3:34-40.

Purwati, E. 2009. Daya hasil tomat hibrida (F1) di dataran medium. J. Hort. 19:125-130.

Rasyad, A., Idwar. 2010. Interaksi genetik x lingkungan dan stabilitas komponen hasil berbagai genotipe kedelai di Provinsi Riau. J. Agron. Indonesia 38:25-29.

Sujiprihati, S., M. Syukur, R. Yunianti. 2006. Analisis stabilitas hasil tujuh populasi jagung manis menggunakan metode Additive Main Effect Multiplicative Interaction (AMMI). Bul. Agron. 34:93-97.

Surmaini, E., E. Runtunuwu, I. Las. 2008. Upaya sektor pertanian dalam menghadapi perubahan iklim. J. Litbang Pertanian 30:1-7.

Suryati, D., M. Chozin, Hasanudin, D. Apriyanto. 2008. Uji multilokasi galur-galur harapan kedelai pada lahan rendah Fosfor. J. Akta Agrosia 11:197-201.

Syukur, M., S. Sujiprihati, R. Yunianti. 2012. Teknik Pemuliaan Tanaman. Penebar Swadaya. Jakarta. 